\title{
2 .地理情報標準の国際的動向と国内の取組の全体像
}

\section{1.はじめに}

1995年の阪神淡路大震災は, 地理情報システム (GIS) の有用性とともに，GISの本格的な利用に向け た取組の緊急性を政府内に再認識させた（GIS 関係省 庁連絡会議，1996）。この時期，欧米の先進各国は，既 にそれぞれの国内の地理情報標準案のとりまとめを終 了し, 米国大統領令12906号（http://www.fgdc.gov/ execord.html）に見られるように，国土空間デー夕基 盤という高度情報通信社会を目指した社会基盤の整備 に国家レベルで取り組んでいた。また，これと並行し て，国際的な地理情報標準に向けた取組も既に始まっ ていた。

我が国は，1980年代後半に「ディジタルマッピング 標準」を完成させたが，ディジタル地四データ作成過 程の標準が中心であったため，地図作成の実務での利 用にとどまり，一般への普及が十分ではなかった。し かし，GISへの関心の高まる中，我が国でも地理情報 標準化の動きが加速してきている。

本稿では，国際的な動向の概要とともに，それを踏 まえた国内地理情報標準の取組の全体像について概観 する。海外における地理情報標準化の取組の詳細につ いては，明野（1997）及び稲葉（1998）を参照された w。

\section{2. 国際標準化の動向}

欧米の先進各国は，1980年代に国内の地理情報の標 準化に取り組んだ。また，北大西洋条約機構(NATO) や国際水路機構（IHO）でも地理情報の標準化が行わ れた。しかし，これらの各国各機関の標準化に向けた 取組は，それぞれのニーズを踏まえて行われたもので あったため，互換性について十分配慮されたものでは なかった。

このような中で, 1993年のフランスの提案により, 国際標準化機構 (ISO) に地理情報に関する専門委員会

*国土地理院

「写真測量とリモートセンシング」VOL. 38, NO. 3, 1999
(TC211) が1994年に設置され, 従来の測量・地四に GIS や画像なども加えた包括的な地理情報標準の検討が始 まった。ISO/TC211 は，「可能な限り情報技術とデー 夕に関する適当な標準とリンクし，また地理デー夕を 利用する分野特有のアプリケーションの開発に枠組み を与える」という考え方に立って作業を進めている。 したがって, 地理情報という表現は使いつつも, 情報 処理の技術標準の一部と位置づけられていることに注 意を要する。

$\mathrm{ISO} / \mathrm{TC} 211$ への参加国数は, 1999年 3 月現在, 投票 権を有する Pメンバー（正式メンバー）が，日本を含 めて 32 力国, 投票権のない $\mathrm{O}$ メンバー(オブザーバー) が15力国である。

検討の開始に当たり, ISO/TC211 は, 20の作業項目 を設定したが，その後 2 つ作業項目を追加し，1998 年の第 7 回総会で 2 つが合併された。また, 1999年 3 月の第 8 回総会で 3 つの作業項目が新設されたため, 検討が進んでいる21の作業項目と設置されたばかりの 3 つの作業項目となった。この21の作業項目とそれぞ れの項目毎に中立的な立場からドラフト作成に責任を 持つプロジェクトリーダーの所属国を表 1 に示す。

当初 ISO/TC211 は，1998年中の完成を目指してい たが，その後の作業項目の新設や検討内容の増加等に より，標準案作成は当初案より遅れ気味である。しか し，困 2 に示すように，ほとんどの作業項目で委員会 ドラフト $(\mathrm{CD})$ が提出されており, 標準の方向が固まっ てきている。1999年 9 月に京都市において開催される 第 9 回 ISO/TC211 総会では, 標準の全体像がさらに 明確になると期待される。

ISO/TC211 と並んでその活動が注目を集めている のが, オープン GIS コンソーシアム (OGC) という 1994 年に設立された米国の非営利の民間団体である。参加 会員数は, GIS ソフトウェア,データベースソフトウェ ア等の民間会社をはじめ，大学や政府機関を含めて約 120である (1999年 4 月時点)。OGC は，相互運用可能 な地理情報処理を実現するための新なな技術，また商 業的な手法確立を推進することを目的としており，特 
表 1 ISO/TC211 の作業項目とリーダー所属国

\begin{tabular}{|c|c|c|c|c|c|}
\hline 番号 & 項 目 名 & リーダー & 番号 & 項 目 名 & リーダー \\
\hline 1 & 参照モデル & アメリカ & 11 & 座標による空間参照 & ドイツ \\
\hline 2 & 概覧 & イギリス & 12 & 地理識別子による空間参照 & イギリス \\
\hline 3 & 概念スキーマ言語 & ノルウェイ & 13 & 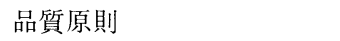 & アメリカ \\
\hline 4 & 用語法 ～～～～～～～～～ & （空席） & 14 & 品質評価手順 & 日本 \\
\hline 5 & 適合性と試験 & 日本 & 15 & メタデータ & アメリカ \\
\hline 6 & プロファイル & カナダ & 16 & 測位サービス & アメリカ \\
\hline 7 & 空間スキーマと空間演算子 & イギリス & 17 & 描画法 & ノルウェイ \\
\hline 8 & 時間スキーマ & アメリカ & 18 & コード化法 & ノルウェイ \\
\hline 9 & アプリケーション・スキーマのための規則 & ノルウェイ & 19 & サービス & ノルウェイ \\
\hline 10 & フィーチャーカタログ化方法論 & アメリカ & 21 & 実用標準 & イギリス \\
\hline & & & 22 & 画像とグリッドデータ & カナダ \\
\hline
\end{tabular}

\section{ISO/TC 211日程表了１999年3月現在}

作業項目

参照モデル

概覧

|| ||||||||||||||||||||||||||||||||||||||||||||||||||||||||||||||||||||||||||||||||

3 D U

3 D UI

3 D UT

3 D UW

3 D UW

3 D UT

3 D UW

3 D UW

概念スキ一マ言語

用語法

適合性亡試験 (日本担当)

空間スキーマと空間演算子 $t * t *$

時間スキーマ

アプリケーションスキーマのための規則 ，

フィーチャカタログ化方法論 座標による空間参照

地理識別子による空間参照

品質原則

品質評価手順(日本担当) $\cdots$

妨データ

測位サービス

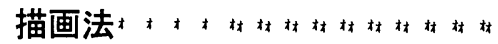

コード化法 $* * * * * \cdots * *$

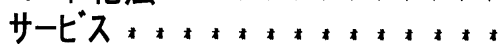

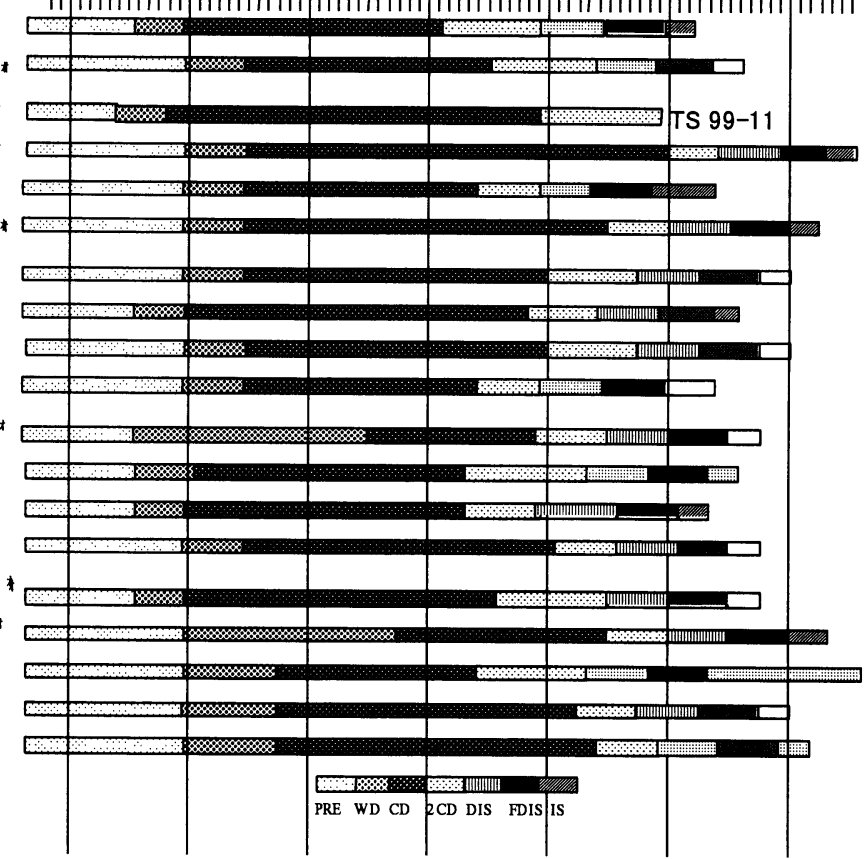

図 1 ISO/TC211 の作業項目毎の検討状況

に, 地理情報の相互運用性を実現するための仕様

(Open Geodata Interoperability Specification; OGIS)の作成を進めている。この仕様が実現されれば, 他のソフトウェアで作成された地理情報を明示的に データ変換することなく, シームレスに利用すること ができるようになるため, 分散ネットワーク環境の下 での GIS 利用が加速されると考えられている（国土空 間デー夕基盤推進協議会, 1997)。
また, 当初独立に進められていた ISO/TC211 と OGCの検討は, 最近になって互いに協力して進めてい くことが合意され，統一標準作成へ向けた作業が加速 していくと考えられている。

3. 国内の取組と課題

3.1 ISO/TC211 の国内審議体制

世界貿易機関 (WTO) の貿易の技術的障害に関する 
（TBT）協定によれば，加盟国は，国家規格を制定する 場合, ISO, IEC 等の国際規格が存在するときはこれに 整合することになっている。このことは, 我が国が ISO の標準を無視した独自の国家規格を作成した場合，そ れが非関税障壁と見なされることを意味する。一方， 我が国にとって不都合な標準が ISO で制定されてし まっては，我が国に大きな不利益をもたらすことにな る。したがって，ISO/TC211における地理情報標準の 検討に対しては，他国任せにするのではなく，我が国 の地理情報標準を作成寸るという考え方で取り組むこ とが必要になってくる。この中には，我が国にとって 不利な標準案に対して反対意見を述べるだけでなく， 標準案作成に積極的に貢献していくということも含ま れる。専門委員会への意見提案等のためには，参加国 は国内審議団体を指定する必要があるが，TC211につ いては，（財）日本測量調查技術協会（測技協）が承認 された。測技協は，ISO/TC211 国内委員会(委員長： 伊理正夫中央大学教授）を設置し，TC211における標 準案検討に参画している。具体的には，表 1 に示され ているように，二つの作業項目について，我が国がド ラフト作成を担当している。

\section{2 国内の地理情報標準作成}

ISO をはじめとした国際的な地理情報標準化の流れ を受けて，これに整合した国内地理情報標準作成の必 要性が認識されるようになったため, 国土地理院は, 1996年度加 3 年間, 建設省官民連带共同研究「GIS の 標準化に関する調査」を実施し，民間企業53社（付録
参照）とともに具体的な国内地理情報標準作成に取り 組んだ。研究推進に当たっては, 空間デー夕標準化委 員会（委員長：伊理正夫中央大学教授）を設置し，学 識経験者等による検討を行った。この共同研究の成果 は，ISO/TC211の標準案を踏まえた我が国初の「地理 情報標準 (第 1 版)」としてまとめられた（空間データ 標準化委員会, 1999)。この地理情報標準の内容は，大 きく二つに分けられる。ひとつは，ISO/TC211 の検討 内容を踏ま之，地理情報の交換のあり方を標準化する 空間デー夕交換標準（以下，「交換標準」）であり，他 のひとつは，交換標準に対応したデー夕整備のための 仕様書作成マニュアル（以下，「作成標準」）である。

交換標準は，ISO/TC211の基本的考之方と同様に， 唯一無二のデータフォーマットを規定するのではな く，異種システム間のデータ交換方法の標準化を目的 としている。そのため, ISO/TC211の全ての作業項目 について検討してはいないが，表 2 に示すように，地 理情報の交換と関係する項目を中心に, 関連する ISO/ TC211 の作業項目を参照しながら標準案を作成した。

作成標準は，デー夕作成工程について規定を設ける 従来の考之方とは異なり, 性能規程の考え方に基づき, デー夕作成発注者側が必要品質に基づいて作成する製 品仕様書の作成方法について技術的な検討を行い，マ ニュアルとしてまとめている。地理情報の製品仕様書 には, デー夕作成の目的，作成項目，デー夕の品質及 び品質評価手法, メタデータの項目等が記述されるこ とを想定しており，これまでは地図縮尺を明記するこ

表 2 交換標準の作業項目

\begin{tabular}{l|l|l}
\hline 研究項目 & ISO 関連項目 & 研究課題 \\
\hline 空間データの構造 & $\begin{array}{l}\text { 空間スキーマ } \\
\text { 時間スキーマ } \\
\text { アプリケーション・スキーマ } \\
\text { のための規則 }\end{array}$ & 地理的オブジェクトの構造の定義 \\
\hline 空間データの品質 & $\begin{array}{l}\text { 品質原則 } \\
\text { 品質評価手順 }\end{array}$ & 空間データの品質及び品質評価手順の作成 \\
\hline 空間参照方法 & $\begin{array}{l}\text { 座標による空間参照 } \\
\text { 地理的識別子による空間参照 }\end{array}$ & 直接参照及び間接参照を用いた空間における位置参照の方法定義 \\
\hline メタデータ & メタデータ \\
\hline 記録仕様 & コード化法 & メタデータの作成 \\
\hline 地理的オブジェクト \\
のカタタグ化
\end{tabular}


とで, データの内容や品質までが半ば自動的に決めら れる場合が多かったが, このマニュアルに基づいて仕 様書を作成すると, 項目の種類を業務の必要に合わせ て自由に選択できるとともに, 項目毎の要求品質を独 立に定めることができる。例えば，都市計画策定のた めの基盤となる地理情報を作成しようとする場合，同 じデータセットの仕様書に, 道路の位置精度を $0.5 \mathrm{~m}$ (標準偏差), 家屋の精度を $1.0 \mathrm{~m}$ (標準偏差) と記述す ることができる。また, デー夕の作成工程は, 受注者 側が作業計画書の中で独自に定めることができるた め, 受注者の有する先進・特殊技術を利用し易くなり, デー夕作成のコスト低減に貢献できると考えられる。 地理情報標準（第 1 版）のとりまとめにより，国内 の地理情報標準が技術的に確立された。しかし，この 標準を地方公共団体等が実務で利用できるようになる ためには, 運用面の検討等の課題が残されており, 早 急な対応が必要になっている。国土地理院では, 1999 年度から公募型の官民共同研究を新たにスタートさ せ, これらの課題について検討を進めるとともに, ISO/TC211の動向についても継続して把握し, 地理情 報標準（第 1 版）の改善と運用の具体化を図る予定で ある。

\section{4. 政府の取組との関係}

政府は，阪神淡路大震災の発生した1995年に GIS 関 係省庁連絡会議（以下，連絡会議）を設置し，GISの 普及及びそのための社会基盤である国土空間デー夕基 盤の整備について，政府として取り組むべき課題の検 討を行ってきた。1996年には, 長期計画(http://www. nla.go.jp/keisei/gis/kaigi/longplan/index.htm) を定
め，1998年度末までを基盤形成期として国土空間デ一 夕基盤の標準化及び整備計画の策定を行い，1999年度 から 3 年間を普及期として, 国土空間デー夕基盤の具 体的整備・更新・普及を行うこととした。連絡会議は, この長期計画に基づき，1999年 3 月に「国土空間デー 夕基盤標準及び整備計画」(以下，標準及び整備計画) を決定した。この標準及び整備計画が定める国土空間 デー夕基盤標準は，大きく二つに分けられる。ひとつ は「技術的な標準」で，ISO/TC211に基づいて定めら れるデータ交換のために必要な標準であり，他のひと つは，基本的な地図データである空間デー夕基盤の項 目を定めた「空間デー夕基盤標準」である。前者は, 「技術的な標準」という表現になっているが，内容は上 述の「地理情報標準 (第 1 版)」と同一である。政府の 取組が普及期に突入し，これから国土空間デー夕基盤 の整備が進む中で,「地理情報標準」についても, 全国 に普及していくものと考えられる。

\section{引用文献}

明野, 1997.「地理情報に関する標準化の動向」, GIS 一理論と応用, 第 5 卷, 2 号, 43-51.

稲葉, 1998.「地理情報システムに関する標準化の動 向」, 第 2 回 “統合型地理情報システム”シンポジウ 么予稿集, 5-27.

国土空間データ基盤推進協議会, 1997.「The OpenGISTM Guide：オープン・ジオデータ相互運用性仕 様 (OGIS) に関する資料」, p.144.

空間デー夕標準化委員会, 1999.「地理情報標準(第 1

版)」, 印刷中.

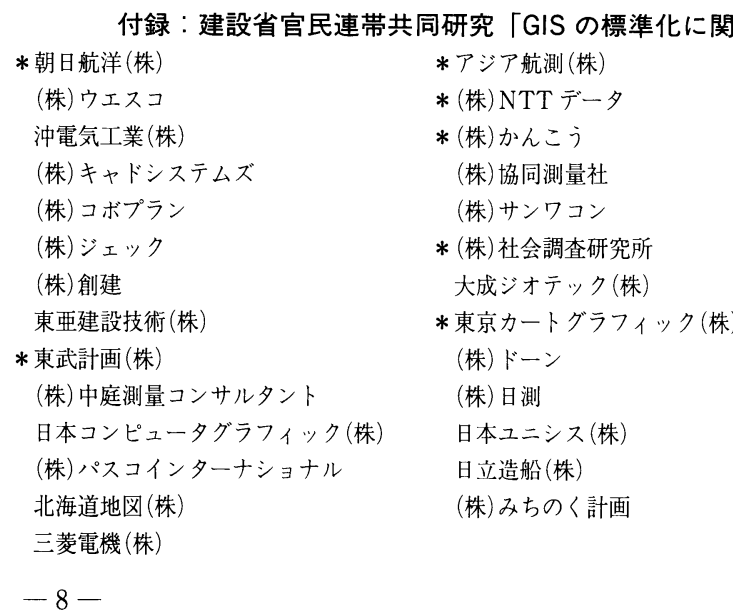

調査」参加企業（五十音順， *印は幹事会社）

(株)石田技術コンサルタンツ 扇精光 (株)

$$
\begin{aligned}
& \text { *(株) インフォマティクス } \\
& \text { (株)オオバ } \\
& \text { (株)キャディックス } \\
& \text { *国際航業(株) } \\
& \text { (株)ジェクト } \\
& \text { (株)ゼンリン } \\
& \text { 玉野総合コンサルタント(株) } \\
& \text { (株)東京地図研究社 } \\
& \text { 中日本航空(株) } \\
& \text { 日本工営(株) } \\
& \text { *(株)パスコ } \\
& \text { 復建調査設計(株) } \\
& \text { 三菱商事(株) }
\end{aligned}
$$$$
\text { (株)きもと }
$$$$
\text { (株) 建設環境研究所 }
$$$$
\text { * (株) CRC 総合研究所 }
$$$$
\text { 昭和(株) }
$$$$
\text { 太平洋航業(株) }
$$$$
\text { *東京ガス (株) }
$$$$
\text { 内外エンジニアリング(株) }
$$$$
\text { *日本アイ・ビー・エム(株) }
$$$$
\text { (株) 八洲 }
$$$$
\text { 富士通 (株) }
$$$$
\text { *三井造船システム技研 (株) }
$$ 